компаниями-конкурентами в данном бизнесе, содержащее информацию о преимуществах или доказывающее преимущества, которыми обладает компания или выпускаемая ею продукция. Обычно используется при выходе на новые рынки, при поглощениях.

С точки зрения частоты информационного обмена, коммуникации могут быть разовыми и периодическими. [2, С. 166].

Регулярное воспроизведение обращений, ориентированных на достижение определенной цели (в том числе, и многократно повторяющаяся реклама) представляет собой запланированную подкрепляющую коммуникацию.

Процесс управления компанией включает в себя установление целей, формирование стратегии, разработку оперативных планов, мониторинг текущих событий, контроль и анализ отклонений фактических результатов от намеченных целей.

Управление может быть представлено как система взаимосвязанных функций: планирование, организация, мотивация и контроль. Оно является эффективным, если оно обеспечивает достижение целей в течение заданного периода времени с минимальными затратами ресурсов.

$$
* * *
$$

1. Киселева И. А., Симонович Н. Е. Психологические аспекты инновационного подхода к обучению руководителей предприятия // Национальные интересы: приоритеты и безопасность. 2013. Т. 9. № 43(322). С. 54-57.

2. Симонович Н. Е. Инновационные подходы к обучению личности: ( психологическая составляющая) // В сборнике: Психология сознания: Истоки и перспективы изучения // Материалы XIV Международных чтений памяти Л. С. Выготского. 2013. С. 166-167.

3. Симонович Н. Е. Инновационные подходы к образованию // В сборнике: Обучение и развитие: современная теория и практика // Материалы XVI Международных чтений памяти Л. С. Выготского. 2015. С. 312.

\title{
Simonovich N.E. \\ The influence of social and psychological factors on social well-being
}

Russian State Humanitarian University

(Rissia, Moscow)

doi: $10.18411 / \mathrm{lj}-12-2019-182$

idsp: ljournal-12-2019-182

\section{Abstract}

The article analyzes the work of modern scientists on the impact of attitudes on the social well-being of people. Examples of interesting experiments are given. Factors that influence people's attitudes and social well-being are also examined in detail. The personality factors and situational factors that affect the well-being of the individual are considered.

Keywords: well-being, personality factor, situational factor, attitudes, experiment, students, researchers, object

The prerequisites for the well-being of people are attitudes if they are in the field of human consciousness, if they are accessible to him. A large number of studies have been devoted to such a feature of attitudes as their "awareness." For example, M. Sniper and W. Swann interviewed students at the University of Minnesota about their attitude to decisive employment policies. Two weeks later, these students were invited to participate in a roleplaying game - to attend the jury at a hearing of an impromptu case of sexual discrimination in hiring. For a group of students who, with the help of special instructions, were given the opportunity to recall their reasoning expressed in the survey, previously formed attitudes influenced their emotional attitude and well-being. Students who did not have the opportunity 
to recall the attitudes to the problem of employment expressed by them at the first stage of the experiment, the attitudes did not affect their emotional attitude and well-being.

An important factor determining the influence of an attitude on well-being is knowledge about the object of this attribute. In this case, the more a person knows about an object, the more accessible the person's attitude is better when evaluating this object, and with a greater probability it is possible to make a forecast about his state of health. This hypothesis was also confirmed in a series of studies conducted by W. Wood. The results showed that attitudes, backed up by a lot of information about the object. To a greater extent determine the well-being of a person.

In the following series of experiments, R. Fasio and M. Zanna, it turned out that attitudes formed on the basis of direct experience better determine behavior than attitudes that arise in any other way. All this happens because they are better fixed in the human memory and are more resistant to various influences. It also became known that such attitudes are more easily retrieved from memory than those based on inferences.

An important confirmation of this thesis was a natural experiment conducted at Cornell University. The reduction in construction allocations forced school management to place some freshmen for several weeks in dormitories, while the rest continued to live in separate rooms. During a survey conducted by D. Regan and R. Fasio, students from both groups equally spoke negatively about the administration's attempts to resolve the problem, thus, and accordingly they had different health conditions. All students were given the opportunity to act in accordance with their attitudes - to sign petitions, collect signatures of students dissatisfied with this state of affairs, join a committee to study the situation, this was done only by those whose attitudes were developed as a result of direct experience related to the housing issue.

We see that the influence of attitudes on well-being is determined by such a characteristic as the strength or accessibility of attitudes. Any accessibility of an entity, in turn, is determined by a high degree of its awareness by the personality, the presence of extensive knowledge about the entity of the entity. Most likely, a social attitude becomes most accessible for regulating well-being when it was formed in direct experience of interacting with an object or repeatedly fixed in the memory of an individual.

About whether attitudes will determine a person's well-being depends not only on the strength of attitudes, but also on personal and situational factors that mediate their relationship. We will attribute it to "internal", personality factors that determine the relationship "attitude - well-being", we will attribute the motivational factor. We considered this when we described the motivational approach.

It follows from this that the "personal interest of a person" can influence the connection between attitudes and well-being. Western psychologists usually understand this as a person's sensation of the degree of importance, the necessity of something life. Any personal interest can be determined, in turn, by both motivational and value factors. At the same time, the more important the result of actions is for a person, the stronger is the connection between the attitude and his well-being. Such a phenomenon was demonstrated by L. Sivatsek and W. Crano during the preparation of a referendum in Michigan regarding the age at which alcohol can be allowed. State authorities decided to raise the age bar from 19 to 21 years. The Michigan referendum was a natural opportunity for L. Sivacek, U. Krano to assess the strength of the influence of personal interest on the relationship of people's attitudes and well-being. To this end, student attitudes were measured in relation to the holding of such a referendum. Two weeks later, all respondents who spoke negatively were invited to join the organization that opposes the referendum and work in the appropriate direction. The survey participants were divided into groups according to the degree of their personal interest, which in this case was explained by age. Among the students were those who were already 21 years old. All of them were defined as "weakly interested". Students who were only 19 years old were included in the group of "highly interested", and finally, those who held an 
intermediate position (20 years) were defined as "moderately interested". Among all students in the three groups, the referendum attitudes were equally negative. Almost all respondents did not differ in the amount of alcohol consumed and in their relation to drink. However, among the three groups there was a significant difference in the number of those who expressed a desire to join the organization to cancel the referendum. So, $47 \%$ of the survey participants, the most interested (age less than 19 years), volunteered to work against holding a referendum. Only $26 \%$ of students in the moderate group agreed to join them, and only $12 \%$ of the oldest students expressed their consent. As a result of this, the connection of the attitudes (in this case, negative in relation to the referendum) and well-being (manifested in the organization of actions against the referendum) was influenced by the students' personal interest in this matter.

We see that one of the important characteristics that mediate the relationship between attitudes and human well-being is self-monitoring. Such a concept was introduced by M. Sniper and means a way of presenting oneself in social situations and regulating one's wellbeing depending on the feelings that are experienced in them. From personal observations, we can say that for some people, well-being is the goal of life. They conduct monitoring, tracking their well-being, significantly change their lifestyle and actions, if they do not experience it. Such people with a high degree of self-monitoring. These people behave like social chameleons - they adjust their well-being to external circumstances, they are very attentive to how others perceive them. Improving their well-being according to the situation, they are ready to fully surrender to the installation, which is not really adhered to. Just by subjecting their lives to constant self-control, such people easily adapt to new jobs, new roles and relationships.

In another case, people with a low level of self-monitoring, on the contrary, pay less attention to how they feel and are accordingly more susceptible to the influence of their social environment. Such individuals are generally more likely to trust their own attitudes. All this was demonstrated in the experiment of M. Snyder and W. Swann. The subjects were asked to play the role of a jury in the gaming trial. They needed to assess the degree of bias of the employer, who hired a man, not a woman. Participants were provided with all the necessary information:

1) on the qualifications of candidates;

2) evidence put forward by both candidates.

The subjects were to reach a verdict and discuss the basis of the decision. The main goal of the experiment was to determine the strength with which the respondents' attitudes regarding gender discrimination affect their social well-being. As a result, respondents with a high level of self-monitoring did not find a connection between attitudes and well-being; for them the information presented about the candidates, about the status and influence of the employer was significant. For all people with weak self-monitoring, their own position in experiencing the situation of sexual discrimination was important. As a result, the well-being of people with low self-monitoring is more correlated with attitudes than people with a high level of self-monitoring [4, p. 188].

Western scientists, in particular G. Triandis, have counted more than 40 different factors that make the connection between mood and well-being more difficult or even inaccessible.

But in the experiments of E. Jones and G. Sigall, as well as R. Page, the difference between personal attitudes and those expressed externally was shown. From the beginning of the experiment, surveys measured attitudes toward black Americans. In total, a positive attitude was recorded among almost all students of the University of Rochester. The next stage, assumed that a certain machine would be demonstrated to students. All subjects had to hold on to a locked wheel, the arrow of which, when released, could turn left and right, respectively indicating a student's disagreement or consent to the question asked by the experimenter. After applying electrodes to students' hands, the imaginary machine allegedly 
began to measure muscle contractions, which caused the wheel to turn left, thereby showing a negative answer, or to the right if there was an answer. In order to demonstrate the operation of the machine, the researcher asked the subjects questions, and the machine itself answered them. As a result of bright flashes and buzzing, the machine issued attitudes of students who were actually nothing more than the data of a study forgotten by everyone. The subjects, unaware of the cunning of the experimenters, were shocked by the capabilities of the machine. When students believed that it was impossible to hide their thoughts from this machine, and therefore it was impossible to hide them from experimenters, the machine was hidden, and at the third stage, a survey was conducted on the attitude to black people. Given the experiment, the survey showed a more negative attitude towards Americans of African descent than in the first series. Now we see that people, both in research and in life, express attitudes that they do not really adhere to, and this ultimately determines their social wellbeing. Any external expression of attitudes will depend on many situational reasons and social influences. Carrying out and studying only expressed attitudes does not make it possible to predict well-being, since it is rather guided by "true" attitudes [1, P. 261]. The uncertainty of the "attitude - well-being" relationship, as American social psychologists believe, may also arise as a result of influences exerted by situational factors on the latter. We will understand situational factors as global social influences, as well as more "private" situational influences. We can consider various levels of social influence - social and cultural, institutional and group, and, finally, interpersonal influences. Such an influence of situational factors on the feelings and moods of people and, accordingly, on their well-being in one form or another has been the subject of consideration of Western social psychology throughout the history of its existence. We will not dwell in detail on even a part of all studies of the influence of situational factors on a person's well-being, we will dwell only on those that are most often mentioned when studying the relationship between attitudes and behavior. These may include:

1) The constant influence on the person's well-being of attitudes and norms of other people (the influence of significant others and group pressure),

2) In all cases, the absence of an acceptable alternative to experiences,

3) Indispensable impact of unpredictable events.

A person who wants to be in harmony with the group, with other people, can give up his attitudes and feel the way most want. With this behavior, his experiences can be determined not by his own, but by other people's attitudes. We remember how during the experiments conducted by S. Ash, many participants succumbed to group pressure - they accepted the majority opinion and were satisfied with this [3, p. 19].

Along with social factors, such variables as the lack of an acceptable alternative, as well as the impact of unpredictable events, can influence the connection between attitudes and people's well-being. When there is no acceptable alternative, we see that the mismatch of the attitudes and well-being is determined by the inability to implement their attitudes in practice, in reality. To give an example, people may be forced to buy those goods that they feel negatively, because there are simply no others. Any impact of unpredictable events is that an unexpected situation forces a person to act sometimes even in spite of his attitudes. Let us take as an example, when a lonely person who does not like his neighbor (negative attitudes), is sick, is forced to turn to her for help and thus adjust his well-being to the situation. [2, p. 163].

Another situational factor that can change the relationship "attitude - well-being" is the lack of time caused by a busy person or an attempt to solve several problems at once. This influence of this situational variable was demonstrated in their witty experiment by J. Darley and D. Batson, whose plot was drawn from the gospel parable of the good Samaritan.

Consider another experiment in which students from Princeton Theological Seminary participated. Students were asked to fill out a questionnaire, the purpose of which was to identify their attitudes toward helping behavior. Almost all students recognized the attitude to 
help others as the most important for themselves. In the course of the experiment, students were given the task of delivering a short, impromptu speech to their comrades in a building not far from their location. It is worth noting that the speech should have been dedicated to the parable of the good Samaritan. After receiving instructions from the experimenter, one subject said: "You are late. You have been waiting for several minutes." Others were told the opposite: "Take your time, you have some time before everything is ready for your arrival." On the way to their destination, the seminarians came across a man who fell in the doorway, who was unable to raise his head, moaned and went into coughing. Only $10 \%$ of late seminarians, we note, with positive attitudes to help, actually provided this help. At the same time, $63 \%$ of the total number of seminarians who had time provided assistance to people. We see that the behavior of the subjects was determined not by attitudes, but by the situation in which they were placed.

An invaluable contribution to the study of situational and dispositional determinants of well-being was made by $\mathrm{K}$. Levin and his students. The main point of situationalism of $\mathrm{K}$. Levin was the thesis that the social context awakens powerful forces that stimulate or limit the well-being of people. However, even the most insignificant characteristics of the situation have the power to change a person's well-being.

Summing up, we can say that studies of Western social psychologists have shown that the state of health was determined by the attitude, if the attitude is associated with the expectations that were previously considered. As a result of the consideration of the problems associated with the problem of defining the concept of "expectation", the concept of attribute is present quite often in intersects much with hypothetical notions of expectation. But the question is how much expectation as an independent and independent unit of study is associated with a constant presence in a particular social situation that affects people's wellbeing.

1. Simonovich N. E. Concept and substantial aspects of social well-being // Bulletin of the RSUU. Series: Psychology. Pedagogy. Education. 2012. No.15. S. 258 -265.

2. Krysko VG, Simonovich N. E. Psychological foundations of the study of people's social well-being in modern Russian society // University Herald. 2001. No. 1. S. 163.

3. Simonovich N. Social well-being as a socially-psychological phenomenon in a changing Russian society // abstract of the dissertation of the candidate of psychological sciences / Moscow, 1999.

4. Simonovich N. E. Socio-psychological characteristics of students // In the collection: Education and development: modern theory and practice // Materials of the XVI International Readings in Memory of L. S. Vygotsky. 2015.S. $188-189$. 